\title{
Barium oxide as a modifier to stabilize the $\gamma-\mathrm{Al}_{2} \mathrm{O}_{3}$ structure
}

\author{
Shahram G. Pakdehi, Maryam Rasoolzadeh*, Ali Saberi Moghadam \\ Malek-Ashtar University of Technology, Faculty of Chemistry and Chemical Engineering, Tehran, Iran \\ "Corresponding author: e-mail: rasoolzadeh21@gmail.com
}

\begin{abstract}
This research concentrated on the structural stability of $\gamma$-alumina $\left(\gamma-\mathrm{Al}_{2} \mathrm{O}_{3}\right)$ was investigated by a combination of differential thermal analysis, X-ray diffractometry and surface-area measurements. The $\gamma$-to- $\theta$ and then $\alpha$ phase transitions were observed as an exothermic peak at $1000^{\circ} \mathrm{C}-1400^{\circ} \mathrm{C}$ in the DTA curves. The role of barium oxide as a modifier to stabilize $\gamma-\mathrm{Al}_{2} \mathrm{O}_{3}$ structure has been investigated. XRD measurements show that after calcination at $1000^{\circ} \mathrm{C}$ for $2 \mathrm{~h}$, a significant fraction of the pure $\gamma-\mathrm{Al}_{2} \mathrm{O}_{3}\left(\mathrm{BaO}\right.$-free) transformed to $\theta-\mathrm{Al}_{2} \mathrm{O}_{3}$ while that the transition phase in alumina samples modified by $\mathrm{BaO}$ have been reduced significantly. Barium oxide, eliminate pentacoordinated aluminum ions through coordinative saturation and alter these ions into octahedral cations and effectively suppressed the $\gamma$-to- $\alpha$ phase transition in $\mathrm{Al}_{2} \mathrm{O}_{3}$, which concluded as improving the thermal stability and porous properties of the experimental samples.
\end{abstract}

Keywords: $\gamma-\mathrm{Al}_{2} \mathrm{O}_{3}$, thermal stability, phase transition, barium oxide, pentacoordinated $\mathrm{Al}^{3+}$ ions.

\section{INTRODUCTION}

$\gamma$-Alumina, one of the metastable "transition" alumina structural polymorphs, is an important catalytic material both as an active phase and as a support for catalytically active phases. Regarding to high level of commercial position and due to wide applications of this material, the bulk and surface structure of $\gamma$-alumina and its formation and thermal stability have been and continue to be subjects of many investigations ${ }^{1}$. The $\gamma$-to- $\theta$ and then $\alpha$ phase transition temperature is important for catalyst and catalyst-support materials used at high temperature, because the specific surface area decreases drastically at the transition, and catalytic activity is lost. Many investigators have reported the effects on the transition temperature of adding various cations ${ }^{2,3}$. There have also been numerous studies dedicated to improving the thermal stability of $\gamma-\mathrm{Al}_{2} \mathrm{O}_{3}$ because its phase transformations are thought to directly affect both the surface area and the number of active sites, which are very important with respect to its practical application. For example, previous studies have shown that the addition of $\mathrm{Mn}^{2+}$ and $\mathrm{Cu}^{2+}$ accelerate the phase transition, $\mathrm{Co}^{2+}, \mathrm{Ni}^{2+}, \mathrm{Mg}^{2+}$, and $\mathrm{Zn}^{2+}$ have little or no effect, but $\mathrm{Ca}^{2+}, \mathrm{Sr}^{2+}$, and $\mathrm{Ba}^{2+}$ have retarding effect on the $\gamma$-to- $\alpha$ phase transition in $\mathrm{Al}_{2} \mathrm{O}_{3}$.

Extensively the subject has been studied in the nature of the surfaces is Lewis acidity. The Lewis acid sites are generated after dehydroxylation of the surfaces and present in the form of coordinatively unsaturated aluminum ions. A large body of studies on this aspect with a variety of techniques such as solid state NMR, FT-IR and theoretical calculations have revealed the presence of three-, four-, and five-coordinate $\mathrm{Al}$ ions in alumina as Lewis acid sites. The removal of $\mathrm{OH}$ groups during high temperature treatment creates coordinatively unsaturated surface cations where tetrahedral $\left(\mathrm{Al}^{\mathrm{IV}}\right)$ and octahedral $\left(\mathrm{Al}^{\mathrm{VI}}\right)$ aluminum coordinations are the most widely accepted ${ }^{5}$. Furthermore, several amounts of pentahedral coordinated aluminum $\left(\mathrm{Al}^{\mathrm{V}}\right)$, concentrated at the surface, have also been found ${ }^{6}$. It has been reported that the $\mathrm{Al}^{\mathrm{V}}$ content is directly related to the pore-size distribution, crystallinity, and surface area ${ }^{7}$. Regarding to acid and base definition of Lewis, uncoordinated me- tal cations and oxide anions on the surface of $\gamma-\mathrm{Al}_{2} \mathrm{O}_{3}$ can act as acids and bases, respectively. The strongest acid sites are considered to be the $\mathrm{Al}^{\mathrm{IV}}$ coordinatively unsaturated surface ions, which are responsible for the high catalytic activity of highly dehydrated alumina. Up to now, the most accepted and frequently used empirical model to describe $\gamma-\mathrm{Al}_{2} \mathrm{O}_{3}$ surfaces was that developed by Knözinger and Ratnasamy9. Accordingly, five different types of $\mathrm{OH}$ groups are present on the surface that exhibit a distinct "net electric charge" $(\sigma)$, depending on the number of $\mathrm{Al}$ neighbors and on $\mathrm{Al}$ coordination. Recently, using density functional theory (DFT) calculations, realistic models of the $\gamma-\mathrm{Al}_{2} \mathrm{O}_{3}$ surface have been proposed that account for the above process ${ }^{10}$. Behavior of various types of surface hydroxyl groups is shown in this model depends on the local chemical environment, morphology (exposed surfaces), and composition of the oxide, which are greatly influenced by the alumina precursors and synthetic methods used.

The ability to control the dispersion and morphology (typical characteristics that determine the performance of catalysts) of oxide-supported metal catalysts is a primary goal of catalyst design and can be enabled by understanding the nature of metal-support surface interactions ${ }^{11}$. Precious metals (e.g., Pt, Pd, Ir and Rh) supported on oxide surfaces are the most widely used industrial catalyst materials. For these classes of catalysts, dispersion of the precious metal on the oxide support is an especially critical factor due to the expense of the metal. One of these catalysts is $\mathrm{Ir} / \gamma-\mathrm{Al}_{2} \mathrm{O}_{3}$ for hydrazine decomposition in gas generators and monopropellant systems. Because of hydrazine decomposition is a highly exothermic reaction to elevate the temperature up to $1000^{\circ} \mathrm{C}^{\mathbf{1 2}-14}$, Therefore, the catalyst should be durable at such high temperature. So the stability of $\gamma-\mathrm{Al}_{2} \mathrm{O}_{3}$ is a critical point for hydrazine decomposition. The $\gamma-\mathrm{Al}_{2} \mathrm{O}_{3}$ phase transforms into the $\delta$ - and $\theta-\mathrm{Al}_{2} \mathrm{O}_{3}$ polymorphs with increasing calcination temperature and finally forms $\alpha-\mathrm{Al}_{2} \mathrm{O}_{3}$, the thermodynamically stable structure?

Investigations on the basis of NMR and IR spectroscopic measurements, showed that the two characteristic ${ }^{27} \mathrm{Al}$ NMR features of $\gamma-\mathrm{Al}_{2} \mathrm{O}_{3}$ at 13 and $70 \mathrm{ppm}$ represent $\mathrm{Al}^{3+}$ ions in octa-hedral $\left(\mathrm{Al}^{3+}\right.$ octa) and tetrahedral $\left(\mathrm{Al}^{3+}\right.$ tetra) coordination, respectively. The NMR peak 
at $35 \mathrm{ppm}$ chemical shift has been assigned to $\mathrm{Al}^{3+}$ ions in pentahedral coordination $\left(\mathrm{Al}^{3+} \text { penta }\right)^{\mathbf{1 5}, 16}$. These pentacoordinate sites are created on the $\gamma-\mathrm{Al}_{2} \mathrm{O}_{3}$ surface by dehydration and dehydroxylation at elevated temperatures. The number of $\mathrm{Al}^{3+}$ penta sites increases with increasing annealing temperature ${ }^{6}$.

Due to the phase transformations affect on both the surface area and number of active sites, improving the thermal stability of $\gamma-\mathrm{Al}_{2} \mathrm{O}_{3}$ for hydrazine decomposition is very important ${ }^{17}$. The role of barium oxide as a modifier to stabilize the $\gamma-\mathrm{Al}_{2} \mathrm{O}_{3}$ structure (and $\mathrm{Ir} /$ $\gamma-\mathrm{Al}_{2} \mathrm{O}_{3}$ catalyst) is investigated in this paper. In this contribution, relation exits between pentacoordinated aluminum ions and the thermal stability of $\gamma-\mathrm{Al}_{2} \mathrm{O}_{3}$. In particular, the specific interaction of barium oxide with these pentacoordinated $\mathrm{Al}^{3+}$ ions is shown to correlate with the observed enhancement of the thermal stability of $\gamma-\mathrm{Al}_{2} \mathrm{O}_{3}{ }^{18}$.

\section{DETAILS EXPERIMENTAL}

The $\gamma-\mathrm{Al}_{2} \mathrm{O}_{3}$ samples used in this work were purchased from Sasol Company. The 2, 6 and $10 \mathrm{wt} \% \mathrm{BaO} / \gamma-\mathrm{Al}_{2} \mathrm{O}_{3}$ samples were prepared by the impregnation method, using an aqueous solution of $\mathrm{Ba}\left(\mathrm{NO}_{3}\right)_{2}$ (Aldrich) and a $\gamma-\mathrm{Al}_{2} \mathrm{O}_{3}$ support. After impregnation, the samples dried at $120^{\circ} \mathrm{C}$ and calcined in a furnace at 600,800 and $1000^{\circ} \mathrm{C}$ for 2 hours.

Supporting Ir catalysts were synthesized using pure $\gamma-\mathrm{Al}_{2} \mathrm{O}_{3}(\mathrm{BaO}$-free $)$ and promoted $\gamma-\mathrm{Al}_{2} \mathrm{O}_{3}$. The preparation method of catalysts is impregnation with $\mathrm{H}_{2} \mathrm{IrCl}_{6}$ (aq) solution.

To determine the $\gamma$-to- $\alpha$ phase transition temperature, differential thermal analysis (DTA) measurements conducted (using a Thermo-Plus Model No. TG8120, Rigaku Co.) at a heating rate of $10^{\circ} \mathrm{C} / \mathrm{min}$, under flowing air $(50 \mathrm{~mL} / \mathrm{min})$, using about $10 \mathrm{mg}$ samples.

The DTA measurements also performed at heating rates of $1^{\circ}, 2^{\circ}, 5^{\circ}$, and $20^{\circ} \mathrm{C} / \mathrm{min}$, to obtain the nonisothermal activation energy for nucleation growth of $\alpha-\mathrm{Al}_{2} \mathrm{O}_{3}$ from the Kissinger equation ${ }^{\mathbf{1 9}}$.

The crystalline phases in the heated samples determined by powder X-ray diffractometry. XRD analysis carried out on a Philips PW3040/00 XPert powder X-ray diffractometer using $\mathrm{Cu} \operatorname{K\alpha }$ radiation $(\lambda=1.5406 \AA)$ in step mode between $2 \theta$ values of 10 and $75^{\circ}$, with a step size of $0.02 \%$.

To examine the changes in the specific surface area, values of the heated samples were determined by the BET method using an automated adsorption instrument (Nova Station A).

SEM analysis was employed to compare dispersion of two types of catalysts $\left(\mathrm{Ir} / \gamma-\mathrm{Al}_{2} \mathrm{O}_{3}\right.$ and $\left.\mathrm{Ir} / \mathrm{BaO} / \gamma-\mathrm{Al}_{2} \mathrm{O}_{3}\right)$ after heated at high temperature. Scanning electron micrographs (SEM) were obtained with Philips XL30 ESEM instrument.

\section{RESULTS AND DISCUSSION}

The $\gamma$-to- $\alpha$ phase transition was observed as an exothermic peak at around $1000^{\circ}-1400^{\circ} \mathrm{C}$ in the DTA curves. The temperatures of the exothermic peaks in the no-additive alumina, $2,6,10 \%$ wt $\mathrm{BaO} / \gamma-\mathrm{Al}_{2} \mathrm{O}_{3}$ were $1208,1320,1355$ and $1300^{\circ} \mathrm{C}$ respectively.
DTA runs show an increase in the $\mathrm{BaO}$ concentration initially causes a corresponding increase in $\alpha-\mathrm{Al}_{2} \mathrm{O}_{3}$ transformation temperature (Fig. 1).

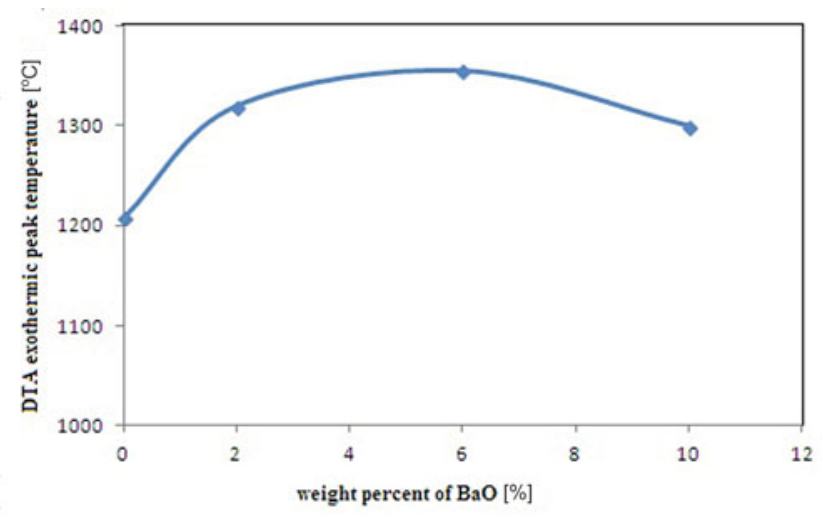

Figure 1. Relationship between the DTA exothermicpeak temperature of the $\gamma-$ to $-\alpha$ phase transition and weight percent of barium oxide

Regarding to increase temperature, $\gamma-\mathrm{Al}_{2} \mathrm{O}_{3}$ changed gradually to $\theta-\mathrm{Al}_{2} \mathrm{O}_{3}$ and, then, $\alpha-\mathrm{Al}_{2} \mathrm{O}_{3}$ as already reported in many papers ${ }^{20}$. Figure 2 represents the XRD patterns of the as-received $\gamma-\mathrm{Al}_{2} \mathrm{O}_{3}$ at $600^{\circ} \mathrm{C}(\mathrm{a}), 800^{\circ} \mathrm{C}$ (b) and $1000^{\circ} \mathrm{C}$. No noticeable structural changes are observed after extended calcination at either $600^{\circ} \mathrm{C}$ (a) or $800^{\circ} \mathrm{C}$ (b). However, several new peaks at $2 \theta$ values of $31.8^{\circ}, 32.9^{\circ}, 51.1^{\circ}$, and $60.3^{\circ}$, assigned to $\theta-\mathrm{Al}_{2} \mathrm{O}_{3}$, are observed in the XRD pattern of the alumina calcined at $1000^{\circ} \mathrm{C}$ for $2 \mathrm{~h}$.

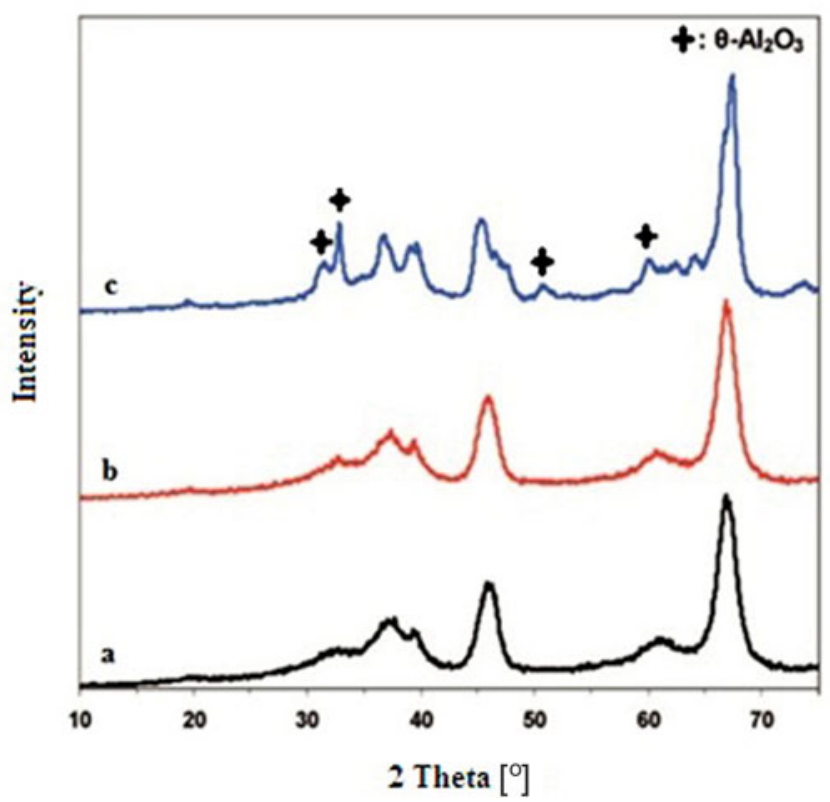

Figure 2. XRD patterns of $\gamma-\mathrm{Al}_{2} \mathrm{O}_{3}$ samples calcined for $2 \mathrm{hrs}$ at (a) $600^{\circ} \mathrm{C}$, (b) $800^{\circ} \mathrm{C}$, and (c) $1000^{\circ} \mathrm{C}$

Figure 3 shows the XRD patterns samples containing different weight percent of $\mathrm{BaO}$ calcined at $1000^{\circ} \mathrm{C}$ for 2h. Figure 3(a) indicates the $\mathrm{BaO}$-free samples. The angles belonging to $\theta-\mathrm{Al}_{2} \mathrm{O}_{3}$ is reduced in Figure 3(b) (2 wt $\%$ BaO-loaded $\gamma-\mathrm{Al}_{2} \mathrm{O}_{3}$ ). In $6 \mathrm{wt} \% \mathrm{BaO}$-loaded $\gamma-\mathrm{Al}_{2} \mathrm{O}_{3}$ sample, peaks related to $\theta-\mathrm{Al}_{2} \mathrm{O}_{3}$ (Fig. 3(c)) are eliminated. By the results of DTA and XRD techniques, the $6 \mathrm{wt} \%$ loading of $\mathrm{BaO}$ is optimized amount to thermal stabilization of $\gamma-\mathrm{Al}_{2} \mathrm{O}_{3}$. 


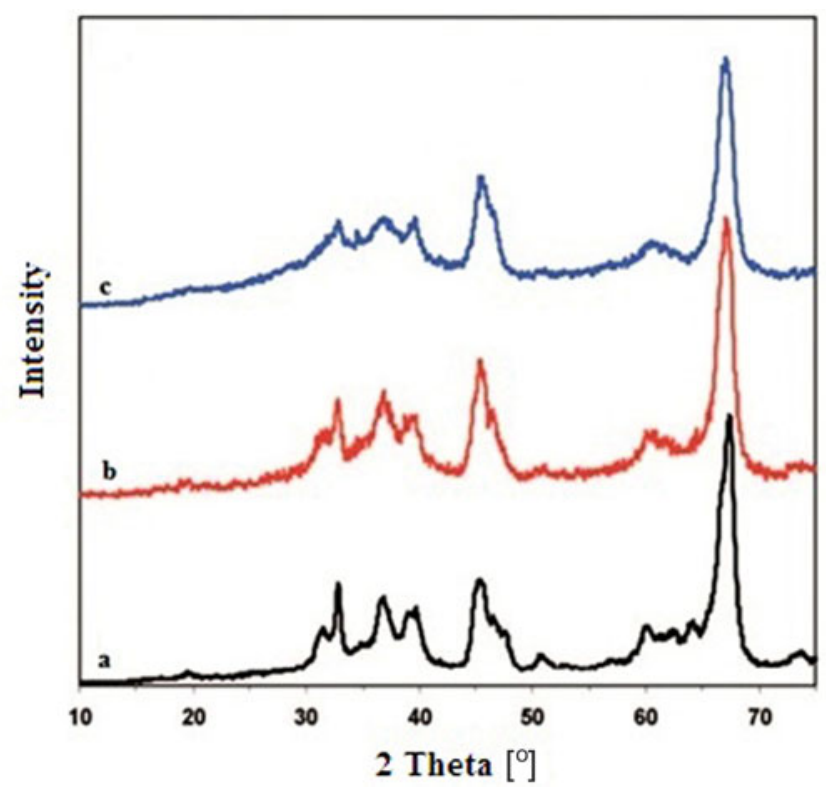

Figure 3. $\mathrm{XRD}$ patterns after being calcined at $1000^{\circ} \mathrm{C}$ for $2 \mathrm{hrs}$ : (a) $\gamma-\mathrm{Al}_{2} \mathrm{O}_{3}$, (b) $2 \%$ wt $\mathrm{BaO} / \mathrm{Al}_{2} \mathrm{O}_{3}$, and (c) $6 \% \mathrm{wt}$ $\mathrm{BaO} / \mathrm{Al}_{2} \mathrm{O}_{3}$

Pentacoordinated aluminum (Alp) ions exist on the surface of $\gamma-\mathrm{Al}_{2} \mathrm{O}_{3}$ can dramatically influence on its structural stability and participate in transition phase from $\gamma$ to $\theta-\mathrm{Al}_{2} \mathrm{O}_{3}$. The role of barium oxide as a modifier retards this phenomenon by saturated the Alp ions and converts them into octahedral ones.

Table 1 also compares the surface area of pure and modified $\gamma-\mathrm{Al}_{2} \mathrm{O}_{3}$ at different temperatures. Pure $\gamma-\mathrm{Al}_{2} \mathrm{O}_{3}$ (without barium oxide) has a specific surface area of $176 \mathrm{~m}^{2} / \mathrm{g}$ after calcination at $600^{\circ} \mathrm{C}$ for $2 \mathrm{~h}$. while that at the same conditions the specific surface area of $\gamma-\mathrm{Al}_{2} \mathrm{O}_{3}$ modified by $6 \mathrm{wt} \% \mathrm{BaO}$ is $170 \mathrm{~m}^{2} / \mathrm{g}$.

Table 1. BET Surface Areas for Alumina Samples as a Function of Calcination Temperature

\begin{tabular}{|l|c|c|c|}
\hline \multirow{2}{*}{ Sample } & \multicolumn{3}{|c|}{ Specific surface area $\left[\mathrm{m}^{2} / \mathrm{g}\right]$} \\
\cline { 2 - 4 } & $600^{\circ} \mathrm{C}$ for $2 \mathrm{~h}$ & $800^{\circ} \mathrm{C}$ for $2 \mathrm{~h}$ & $1000^{\circ} \mathrm{C}$ for $5 \mathrm{~h}$ \\
\hline $\mathrm{Y}-\mathrm{Al}_{2} \mathrm{O}_{3}$ & 176 & 172 & 103 \\
\hline $6 \mathrm{wt} \% \mathrm{BaO} / \mathrm{Y}-\mathrm{Al}_{2} \mathrm{O}_{3}$ & 170 & 168 & 115 \\
\hline
\end{tabular}

Increasing the calcination temperature to $800^{\circ} \mathrm{C}$ resulted in very similar decreases in the specific surface areas of both of these materials, regardless of the presence or absence of $\mathrm{BaO}$. Specific surface areas of $\gamma-\mathrm{Al}_{2} \mathrm{O}_{3}$ and 6 wt $\% \mathrm{BaO}$-doped $\gamma-\mathrm{Al}_{2} \mathrm{O}_{3}$ at $800^{\circ} \mathrm{C}$ were $172 \mathrm{~m}^{2} / \mathrm{g}$ and 168 $\mathrm{m}^{2} / \mathrm{g}$ respectively. Further calcination at $1000^{\circ} \mathrm{C}$ for $2 \mathrm{~h}$ significantly reduced the specific surface areas of both of these samples. Increasing the calcination temperature to $1000^{\circ} \mathrm{C}$ showed the specific surface area of $103 \mathrm{~m}^{2} / \mathrm{g}$ for $\gamma-\mathrm{Al}_{2} \mathrm{O}_{3}$ and $115 \mathrm{~m}^{2} / \mathrm{g}$ for $\mathrm{BaO} / \gamma-\mathrm{Al}_{2} \mathrm{O}_{3}$. However specific surface area of promoted sample is more than $\gamma-\mathrm{Al}_{2} \mathrm{O}_{3}$.

The iridium supported on $\gamma-\mathrm{Al}_{2} \mathrm{O}_{3}$ and $\mathrm{BaO} / \gamma-\mathrm{Al}_{2} \mathrm{O}_{3}$ catalysts were prepared by the impregnation method ${ }^{14}$ for decomposition of hydrazine. To compare the thermal stability of these catalysts, the samples were heated at $1000^{\circ} \mathrm{C}$ for 2 hours. SEM and BET measurements were employed to determine their changes.

As it may be seen in Figure 4, after heated at $1000^{\circ} \mathrm{C}$ for 2 hours, the dispersion of particles in iridium based on promoted gamma alumina support is better.
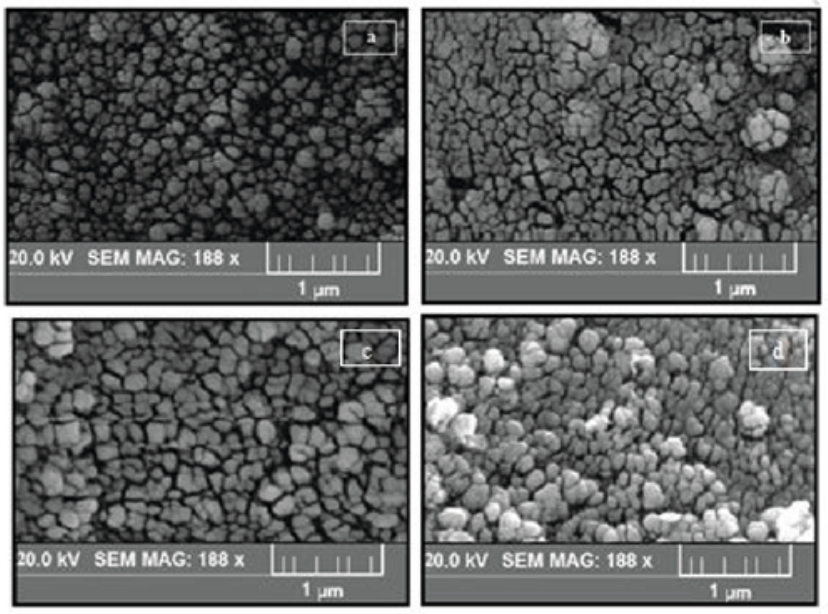

Figure 4. Micrographs of $\mathrm{Ir} / \mathrm{BaO} / \gamma-\mathrm{Al}_{2} \mathrm{O}_{3}$ and $\mathrm{Ir} / \gamma-\mathrm{Al}_{2} \mathrm{O}_{3}$ catalysts $\mathrm{a}, \mathrm{c})$ before, and $\mathrm{b}, \mathrm{d})$ after being heated at $1000^{\circ} \mathrm{C}$ for $2 \mathrm{hrs}$

Table 2 indicates the specific surface area of two catalysts before and after heated at $1000^{\circ} \mathrm{C}$ for 2 hours. Specific surface area of $\mathrm{Ir} / \gamma-\mathrm{Al}_{2} \mathrm{O}_{3}$ catalyst is much more decreased after being heated at $1000^{\circ} \mathrm{C}$ than $\mathrm{Ir} / \mathrm{BaO} / \gamma-\mathrm{Al}_{2} \mathrm{O}_{3}$.

Table 2. specific surface area before and after heated at $1000^{\circ} \mathrm{C}$ for $2 \mathrm{hrs}$

\begin{tabular}{|l|c|c|}
\hline Sample & Before & After \\
\hline $\mathrm{Ir} / \mathrm{Y}-\mathrm{Al}_{2} \mathrm{O}_{3}$ & 139 & 70 \\
\hline $\mathrm{Ir} / \mathrm{BaO} / \mathrm{Y}-\mathrm{Al}_{2} \mathrm{O}_{3}$ & 130 & 84 \\
\hline
\end{tabular}

\section{CONCLUSIONS}

The effects of barium oxide on $\gamma$ - to $\theta$ and $\alpha$ phase transition for $\mathrm{Al}_{2} \mathrm{O}_{3}$ were examined by using a combination of DTA, XRD and BET techniques. DTA analysis show that the $\alpha-\mathrm{Al}_{2} \mathrm{O}_{3}$ transformation temperature is increased from $1200^{\circ} \mathrm{C}$ to about $1360^{\circ} \mathrm{C}$ at $6 \%$ barium oxide doping. The results of the XRD indicate that at about $1000^{\circ} \mathrm{C} \gamma-\mathrm{Al}_{2} \mathrm{O}_{3}$ alters to $\theta-\mathrm{Al}_{2} \mathrm{O}_{3}$ phase, but addition of $\mathrm{BaO}$ prevents the $\gamma$ phase and has retarding effect.

Regarding to experimental results, it may propose that formation temperature of $\theta-\mathrm{Al}_{2} \mathrm{O}_{3}$ is about $900-1000^{\circ} \mathrm{C}$. At high temperature $\left(>950^{\circ} \mathrm{C}\right)$ pentacoordinated aluminum ions became unstable, so transition to $\theta-\mathrm{Al}_{2} \mathrm{O}_{3}$ occurred. In the other words the transformation from $\gamma$ - to $\theta$ and then $\alpha-\mathrm{Al}_{2} \mathrm{O}_{3}$ happens only in the presence of Alp (Pentacoordinated aluminum ions) sites. In case of the addition of $\mathrm{BaO}$, coordination of pentahedral aluminum ions saturated and therefore instability of $\gamma-\mathrm{Al}_{2} \mathrm{O}_{3}$ reduced. The addition of barium oxide effectively suppressed the $\gamma$-to- $\alpha$ phase transition in $\mathrm{Al}_{2} \mathrm{O}_{3}$ and increased its thermal stability and porous properties in iridium catalyst.

\section{LITERATURE CITED}

1. Kopanda, J., MacZura, G. \& Hart, L. (1990). Alumina Chemicals, Science and Technology Handbook. In Alumina Chemicals, Science and Technology Handbook.

2. Yoldas, B.E. (1976). Thermal stabilization of an active alumina and effect of dopants on the surface area. J. Mat. Sci. 11, 465-470. DOI: 10.1007/BF00540927.

3. Ozawa, M., Kato, O., Suzuki, S., Hattori, Y. \& Yamamura, M. (1996). Sintering and phase evolution of $\gamma-\mathrm{Al}_{2} \mathrm{O}_{3}$ with transition-metals addition at around $\alpha$-transition temperature. J. Mat. Sci. Lett. 15, 564-567. DOI: 10.1007/BF00579251. 
4. Mei, D., Kwak, J.H., Hu, J., Cho, S.J., Szanyi, J., Allard, L.F. \& Peden, C.H.F. (2010). Unique Role of Anchoring PentaCoordinated $\mathrm{Al}^{3+}$ Sites in the Sintering of $\gamma-\mathrm{Al}_{2} \mathrm{O}_{3}$-Supported Pt Catalysts. J. Phys. Chem. Lett. 1, 2688-2691. DOI: 10.1021/ jz101073p.

5. Paglia, G., Buckley, C.E., Rohl, A.L., Hart, R.D., Winter, K., Studer, A.J., Hunter, B.A. \& Hanna, J.V. (2004). Boehmite derived $\gamma$-alumina system. 1 . Structural evolution with temperature, with the identification and structural determination of a new transition phase, $\gamma$-alumina. Chem. Mat. 16, 220-236. DOI: $10.1021 / \mathrm{cm} 034917 \mathrm{j}$.

6. Pecharroman, C., Sobrados, I., Iglesias, J.E., Gonzalez-Carreno, T. \& Sanz, J. (1999). Thermal evolution of transitional aluminas followed by NMR and IR spectroscopies. J. Phys. Chem. B. 103, 6160-6170. DOI: 10.1021/jp983316q.

7. Tsyganenko, A.A. \& Mardilovich, P.P. (1996). Structure of alumina surfaces. J. Chem. Soc. Faraday Trans 92, 4843-4852. DOI: 10.1039/FT9969204843.

8. Busca, G. (1998). Spectroscopic characterization of the acid properties of metal oxide catalysts. Catal Today 41, 191-206. DOI: 10.1016/S0920-5861(98)00049-2.

9. Morterra, C. \& Magnacca, G. (1996). A case study: surface chemistry and surface structure of catalytic aluminas, as studied by vibrational spectroscopy of adsorbed species. Catal Today 27, 497-532. DOI: 10.1016/0920-5861(95)00163-8.

10. Digne, M., Sautet, P., Raybaud, P., Euzen, P. \& Toulhoat, H. (2002). Hydroxyl groups on $\gamma$-alumina surfaces: A DFT study. J. Catal. 211, 1-5. DOI: 10.1006/jcat.2002.3741.

11. Bravo-Suárez, J.J., Chaudhari, R.V. \& Subramaniam, B. (2013). Design of Heterogeneous Catalysts for Fuels and Chemicals Processing: An Overview. Am. Chem. Soc.). DOI: 10.1021/bk-2013-1132.ch001.

12. Armstrong, W.E., Ryland, L.B. \& Voge, H.H. (1978). Catalyst Comprising Iridium or iridium-ruthenium catalyst for hydrazine decomposition. In US patent no. 4124538.: U.S. Patent and Trademark Office.

13. Kappenstein, C. \& Joulin, J. (2006). Ceramics as Catalysts and Catalyst Supports for Propulsion Applications-The Objectives and the Challenges. Adv. Sci. Technol. (Trans. Tech. Publ.), 2143-2152. DOI: 10.4028/www.scientific.net/AST.45.2143.

14. Pakdehi, S., Rasoolzadeh, M. \& Zolfaghari, R. (2014). Synthesize and Investigation of the Catalytic Behavior of $\mathrm{Ir} / \gamma$ $-\mathrm{Al}_{2} \mathrm{O}_{3}$ Nanocatalyst. Adv. Mater. Res. 829. 163-167. DOI: 10.4028/www.scientific.net/AMR.829.163.

15. Kwak, J.H., Hu, J., Mei, D., Yi, C.W., Kim, D.H., Peden, C.H.F., Allard, L.F. \& Szanyi, J. (2009). Coordinatively Unsaturated $\mathrm{Al}^{3+}$ Centers as Binding Sites for Active Catalyst Phases of Platinum on $\gamma-\mathrm{Al}_{2} \mathrm{O}_{3}$. In Science 1670-1673. DOI: 10.1126/science.1176745.

16. Chen, F.R., Davis, J.G. \& Fripiat, J.J. (1992). Aluminum Coordination and Lewis Acidity in Transition Aluminas. J. Cat. 133, 263-278. DOI: 10.1016/0021-9517(92)90239-E.

17. Santos, P.S., Santos, H.S. \& Toledo, S.P. (2000). Standard Transition Aluminas. Electron Microscopy Studies. Mater. Res. 3, 104-114. DOI: 10.1590/S1516-14392000000400003.

18. Kwak, J.H., Hu, J.Z., Kim, D.H., Szanyi, J. \& Peden C.H.F. (2007). Penta-coordinated $\mathrm{Al}^{3+}$ ions as preferential nucleation sites for $\mathrm{BaO}$ on $\gamma-\mathrm{Al}_{2} \mathrm{O}_{3}$ : An ultra-high-magnetic field 27Al MAS NMR study. J. Catal. 251, 189-194. DOI: 10.1016/j.jcat.2007.06.029.

19. Kissinger, H.E. (1957). Reaction kinetics in differential thermal analysis. Anal. Chem. 29, 1702-1706. DOI: 10.1021/ ac60131a045.

20. Nguefack, M., Popa, A.F., Rossignol, S. \& Kappensteina, C. (2003). Preparation of alumina through a sol-gel process, synthesis characterization, thermal evolution and model of intermediate Boehmite. Phys. Chem. Chem. Phys. 5, 4279-4289. DOI: 10.1039/B306170A. 